\title{
Urban Material Flow Analysis: An approach for Greater Kuala Lumpur
}

\author{
Farah Ayuni Shafie ${ }^{1,2}$, Dasimah Omar², \\ Subramaniam Karuppannan ${ }^{1}$, Nurhayati Shariffuddin ${ }^{1}$ \\ ${ }^{1}$ Faculty of Health Sciences, Universiti Teknologi MARA, Puncak Alam, Selangor, Malaysia \\ 2 Faculty of Architecture, Surveying and Planning, Universiti Teknologi MARA, Shah Alam, Selangor, Malaysia \\ farahayuni@salam.uitm.edu.my
}

\begin{abstract}
The objective of the study was to estimate environmental impacts of the cities in Greater Kuala Lumpur, Malaysia: Kajang, Sepang, and Putrajaya by using material flow analysis. The study assessed prime material flows within three cities in Malaysia; electricity consumption, water usage, food consumption, carbon dioxide emission, wastewater production and solid waste. A functional unit of $\mathrm{kg} / \mathrm{cap} / \mathrm{day}$ was defined for all the material flows. Putrajaya was seen as the highest consumer of water, even with the lowest population. Kajang contributed the most of in terms of environmental impacts, followed by Sepang and Putrajaya.

Keywords: material flow analysis, urban management, resource consumption

eISSN 2398-4279 @ 2018. The Authors. Published for AMER ABRA CE-Bs by e-International Publishing House, Ltd., UK. This is an open access article under the CC BY-NC-ND license (http://creativecommons.org/licenses/bync-nd/4.0/). Peer-review under responsibility of AMER (Association of Malaysian Environment-Behaviour Researchers), ABRA (Association of Behavioural Researchers on Asians) and CE-Bs (Centre for EnvironmentBehaviour Studies), Faculty of Architecture, Planning \& Surveying, Universiti Teknologi MARA, Malaysia.

https://doi.org/10.21834/ajqol.v3i11.135
\end{abstract}




\subsection{Introduction}

Cities are growing in multi-faceted ways due to their size, social structures, economics systems, geopolitical settings and the evolution of technology. Therefore, the city agenda towards sustainability seek approaches that could assess environmental impacts as energy and resource mitigation is a prevailing issue in any national context. The capital city of Malaysia; Kuala Lumpur and its neighbouring cities will undergo conurbation as planned in the Malaysian Economic Transformation Program to avert strain of rapid change by putting growth parallel to city's liveability (Malaysia Performance Management \& Delivery Unit, 2016). It is natural that urban development fragments, isolates and degrades natural habitats, disrupts hydrological systems and modifies energy flows and nutrient cycling (Mabahwi, et al., 2015). The key to manage the city's environmental management could be the quantification of the material flows coming in and going out of the city which carries more weight and can prove more influential.

\subsection{Literature Review}

There are cases of pollutions due to inability to manage resources; for example, water usage in cities often at risk from climate change, due to sudden changes in quality and quantity of water, higher temperature and intense rain and high volume may result in flash floods, drop in water tables and reduced availability of surface water (Singh \& Mishra, 2014). Other environment aftermaths due to unsustainable development are air pollution (Sadorsky, 2014), formation of urban heat island (Shahmohamadi et al, 2011), contamination of water catchment areas by landfill leachate (Victor \& Agamuthu, 2013) and environmental degradation (Gao \& Liu, 2012).

Sustainable city analysis and management requires understanding of the demands a city places on a wider geographical area and its ecological resource base. The overall goal of material flow analysis is to demonstrate the application of a bottom-up environmental analysis using an urban metabolism framework (Moore et al, 2013). Policy makers and urban managers may have to quantitatively analyse physical input-output relationship among urban components, thereby providing scientific support to structure the urban metabolic system and material flow analysis could be the underlying structural attributes.

\subsection{Methodology}

\subsection{Study design}

Material Flow Analysis assists in understanding the resource use efficiencies, recycling of wastes and conservation of energy (Shafie et al., 2013; Wang et al., 2015). The study applied material flow analysis at the city level; a method to examine a given system by accounting for all its material inputs, the material accumulations and its outputs within a system boundary. All materials are simply put into a cycle, where they are then consumed to create biophysical structures i.e. human bodies, tools, agricultural crops and export products and 
create waste (Pincetl, Bunje, \& Holmes, 2012). Inputs in this study are; "energy inputs", "water inputs", and "food and drinks inputs". After material distribution in the cycle, three types of outputs are accounted for: "air emission" as in carbon dioxide, "wastewater" and "solid waste". The conceptual framework of the study is illustrated in Figure 1.

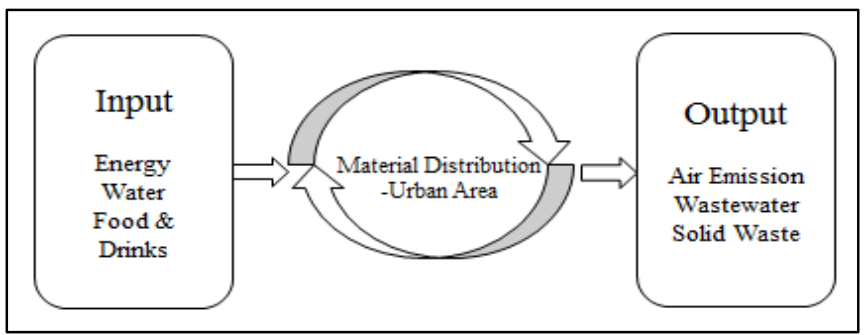

Figure 1: Urban-scaled Material Flow Analysis framework

\subsection{Study Location and Variables}

Three districts in Greater Kuala Lumpur/Klang Valley conurbation cities: Kajang, Sepang and Putrajaya were selected due to the characteristics of the cities where Sepang is considered partially well-planned, Kajang is a heavily populated and unplanned city while Putrajaya is a planned city and act as the Federal Government Administrative Center for Malaysia. The boundary of the study areas in Greater Kuala Lumpur is illustrated in Figure 2.

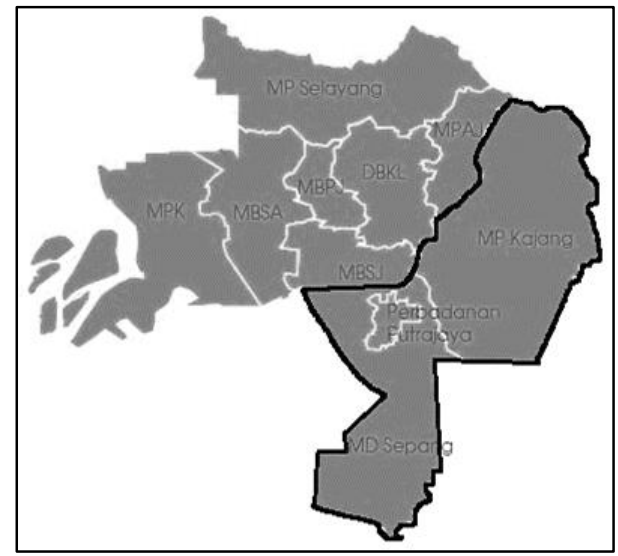

Figure 2: The three localities

Independent variables that are considered were; economic activities and number of population, while the dependent variables were; energy, water and food and drinks (rice, eggs, and sugar) consumptions, and air emission (carbon dioxide), solid waste and wastewater production. The difference of the cities are identified according to urbanisation level, social lifestyle and affluence. The consumption data were gathered and converted in a 
uniform unit of kilogram/cap/day.

The study has undertaken two methods; 1) administering questionnaire to obtain primary data of resource usage and behaviour study of the population and 2) secondary national data that has been published by respective authorities such as Energy Commission Malaysia for electricity, Syarikat Bekalan Air Selangor (SYABAS) for treated water use, Food and Agriculture (FAO) for food consumption, Department of Environment (DOE) for air quality, Indah Water Konsortium (IWK) for waste water production and Alam Flora and Worldwide for solid waste production. Data were then downscaled to obtain consumption and production per capita per day.

\subsection{Findings and Discussions}

The findings of the study are divided into two sections: resource inputs and outputs, and material flows.

\subsection{Resource input and outputs}

Table 3 depicts the overall resource consumption for the whole of Klang Valley/Greater Kuala Lumpur together with consumption according to the localities. From the $p$-value of statistical analysis, it can be drawn that for electricity use, there is no significant difference between the three localities. As for water usage, there is a significant difference between the three localities. Lastly, for food consumption, there is no significant difference among the study localities.

Table 3. Resource use and waste production for Greater Kuala Lumpur

\begin{tabular}{|c|c|c|c|c|c|}
\hline \multirow[t]{2}{*}{ Inputs } & \multicolumn{2}{|c|}{$\begin{array}{l}\text { Residential Use in } \\
\text { Klang Valley } \\
\text { (kg/cap/day) } \\
\text { Energy *(koe/cap/day) }\end{array}$} & \multicolumn{3}{|c|}{$\begin{array}{l}\text { Overall Use and Production for Each Locality } \\
\qquad \begin{array}{c}(\mathrm{kg} / \text { day) } \\
\text { Energy *(koe/day) }\end{array}\end{array}$} \\
\hline & \multicolumn{2}{|c|}{$\begin{array}{c}\text { Klang Valley } \\
7002565\end{array}$} & $\begin{array}{c}\text { Kajang } \\
342,657\end{array}$ & $\begin{array}{l}\text { Sepang } \\
207,354\end{array}$ & $\begin{array}{c}\text { Putrajaya } \\
68,785\end{array}$ \\
\hline $\begin{array}{l}\text { Energy } \\
\text { (Electricity) }\end{array}$ & \multicolumn{2}{|c|}{0.188} & 64419.5 & 39982.5 & 12931.6 \\
\hline Water & \multicolumn{2}{|c|}{236.1} & 80902317.7 & 48956279.4 & 16240138.5 \\
\hline \multirow{4}{*}{ Food } & Rice & 0.24 & 82237.68 & 49764.96 & 16508.4 \\
\hline & Egg & 0.06 & 20559.42 & 12441.24 & $4,127.1$ \\
\hline & Sugar & 0.08 & 27412.56 & 16588.32 & 5502.8 \\
\hline & Total & 0.38 & 130209.7 & 78794.5 & 26138.3 \\
\hline Gases & \multicolumn{2}{|c|}{0.455} & 155908.9 & 94346.1 & 31297.2 \\
\hline Wastewater & \multicolumn{2}{|c|}{225} & 77097825 & 46654650 & 15476625 \\
\hline Solid Waste & \multicolumn{2}{|c|}{4.5} & 1541956.5 & 933093 & 309532.5 \\
\hline
\end{tabular}

The highest mean of electricity consumption is for Kajang, followed by Sepang and Putrajaya. The use of energy and natural resources rises in parallel with the rise of modern consumerism. Consumers in Malaysia are aware of energy conservation and are looking for 
better products in term of energy saving and fuel efficiency where the living cost is more directly incurred (Tan et al., 2013).

For water consumption, Putrajaya has the highest consumption of water, even though it has the least population. Putrajaya being the planned city, may lead the sustainable water management effort on efficient use of water and more sustainable water consumption behaviour. The concept of rainwater harvesting or greywater recycling can be integrated water management may be introduced into individual site and building design. Rainwater harvesting implemented at a macro level i.e. municipality helps to provide stormwater reduction that prevents flooding downstream during monsoon season and will typically enhance river water quality. The creation of large retention pond and artificial wetlands also provide landscape amenity for the community. It helps to secure water for irrigation to reduce the urban heat island and reducing clean-up costs from pollution incidents and flood (Suhaimi et al., 2014).

A food supply chain starts from the food production to where it is consumed in its final form (Alfonso Piña W.H., Pardo Martínez, 2014). Putrajaya lead in the highest food consumption, followed by Kajang, and Sepang. Organic matter from this food chain supply, in this current linear and open system is not recyclable unlike a stable ecosystem. In this urban area, the diverse eating habit and the practice of eating-out has become a trend among urban workers, students and even families because of work or there is no food available at home (World Economic Forum, 2011). National waste policy could benefit from the emphasis on recycling strategies especially from households where the inefficiency in the ecosystem can be reduced.

Kajang has the highest population thus contribute to highest outputs of gases, wastewater and solid waste. Kajang with the highest population number of 342,657 people and highest density rate of 10.36 , and as the most populated area out of three districts, the higher the possibility of inefficiency of resource management thus increase the exposure of population to environmental effects. Sepang has the population of 207,354 of people, comparatively, which places it in the second place after Kajang. Its total population is $60 \%$ of Kajang's population, and shows second highest of consumption of resources and production of wastes. At 0.004 population density rate, the exposure of environmental impacts towards the populations is marginally lowered due to various land use and it helps in maintaining the population and environmental sustenance (Malaysia Performance Management \& Delivery Unit, 2016). As for Putrajaya, the total population is only $20 \%$ of Kajang's, making it acceptable for this locality to use the least and produce the least of waste among three study areas. With the population density of 0.002 , it is shown that Putrajaya, the systematically planned city, the resource management efficiency has been carefully thought of, and prevention of waste has been implemented, such as recycling activities. Having mentioned that, Putrajaya contributed the least to environmental impacts in the sense of output production.

\subsection{Material flow}

All the material flows are converted to kilogram/cap/day as a single standard unit while for energy consumption, the unit is set to kilogram of oil equivalent per capita per day 
(koe/cap/day). This material flow is established together with three other sister cities: Kuala Lumpur, Ampang Jaya and Selayang: studied for the remaining of the Greater Kuala Lumpur (Shafie et al, 2016). The movement of energy, water, food and drinks, gases, wastewater and solid waste are plotted and illustrated in Figure 3.

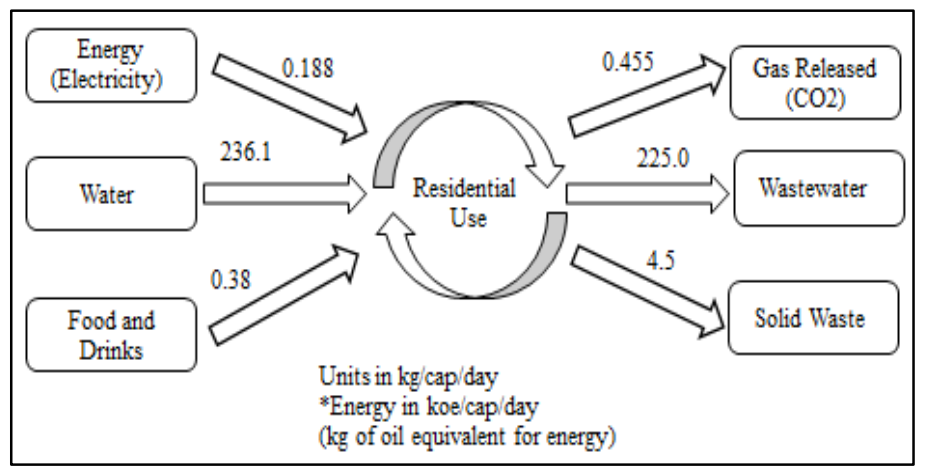

Figure 2. Material Flow Analysis fchart for Greater Kuala Lumpur

The material flow for the Greater Kuala Lumpur esulted with these inferences: 1) 0.188 koe/cap/day of energy emits $0.455 \mathrm{~kg} / \mathrm{cap} /$ day of carbon dioxide. 2) with $236.1 \mathrm{~kg} / \mathrm{cap} /$ day of water usage, $95.3 \%$ became wastewater. 3) As for solid waste, $0.38 \mathrm{~kg} / \mathrm{cap} / \mathrm{day}$ of food consumption produce $4.5 \mathrm{~kg} / \mathrm{cap} /$ day of solid waste.

\subsection{Conclusion}

Cities expose people to the range of consumption trend. Enhanced urban management should be able to monitor the input and output flow of the consumption. Material Flow Analysis is one of the tools of urban metabolism that can be used to identify the resource efficiency management in a city, state, or even an industry. In this study, it is shown that the hypothesis of properly planned city will have lower environmental impacts is true. Kajang is highly populated, has highest population density and develop through accommodating demands of urban sprawl. The city has shown by highest use of resources and highest wastes production, followed by Sepang, and Putrajaya. Strategic data collection and reporting may increase resource efficiency, such as improved data collection, compilation and analysis of related governmental agencies, application of policy of rain harvesting, application of green urbanism, properly planned food production and properly planned accommodation plan. The new direction and future plan should consider keeping official and reliable records of the material flows coming in and out from the region.

As the world urbanises, cities must assume an ever-greater role in determining sustainability outcomes. Quantification of the co-benefits in a city is a challenge but certainly will ensure a comprehensive base upon which an appropriate decision on consumption and emission reduction target to be made. Causalities that are occurring among all the metabolic 
components of the urban environment can be identified and specific intervention measures can be taken up by the local governments. Urban material flow analysis may be used to intensify resource use efficiency, recycling of waste and conservation of energy by examining the interaction between natural - human systems that impact developed and developing cities.

\section{References}

Alfonso Piña W.H., Pardo Martínez, C.I. (2014) Urban material flow analysis: an approach for Bogotá, Colombia. Ecol. Indic., 42, 32-42.

Gao, J., \& Liu, Y. (2012). Deforestation in Heilongjiang Province of China, 1896-2000: Severity, spatiotemporal patterns and causes. Applied Geography, 35(1-2), 345-352.

Mabahwi, N. A., Ling, O. H. L., \& Omar, D. (2015). Urban Air Quality and Human Health Effects in Selangor, Malaysia. Procedia - Social and Behavioral Sciences, 170, 282-291.

Malaysia Performance Management \& Delivery Unit (2016). Economic Transformation Plan. Retrieved from http://www.pemandu.gov.my/contact.aspx

Moore, J., Kissinger, M., \& Rees, W. E. (2013). An urban metabolism and ecological footprint assessment of Metro Vancouver. Journal of Environmental Management, 124, 51-61.

Rahman, S. A., \& Khalid, Rasyikah Md, Sahat, R. (2014). Sustainable Water Management: A Case Study of Putrajaya Malaysia. In University of Hong Kong (Ed.), Igarss 2014 (pp. 1-5). 16th Annual International Sustainable Development Research Conference 2010.

Rosado, L., Niza, S., \& Feraao, P. (2014). A Material Flow Accounting Case Study of the Lisbon Metropolitan Area using the Urban Metabolism Analyst Model. Journal of Industrial Ecology, 18(1), 84-101.

Shafie, F. A., Omar, D., \& Karuppannan, S. (2013). Environmental Health Impact Assessment and Urban Planning. Procedia - Social and Behavioral Sciences, 85, 82-91.

Shafie, F. A., Omar, D., Karuppannan, S., \& Ismail, N. (2016). Urban-scale Material Flow Analysis: Malaysian Cities Case Study. International Journal of Environment and Sustainability, 5(2), 104.

Singh, S., \& Mishra, A. (2014). Deforestation-induced costs on the drinking water supplies of the Mumbai metropolitan, India. Global Environmental Change, 27, 73-83.

Tan, C. S., Maragatham, K., \& Leong, Y. P. (2013). Electricity energy outlook in Malaysia. IOP Conference Series: Earth and Environmental Science, 16, 012126.

Victor, D., \& Agamuthu, P. (2013). Strategic environmental assessment policy integration model for solid waste management in Malaysia. Environmental Science \& Policy, 33,

Wang, Q., Yuan, X., Zhang, J., Mu, R., Yang, H., \& Ma, C. (2013). Key evaluation framework for the impacts of urbanization on air environment - A case study. Ecological Indicators, 24, 266-272.

World Economic Forum. (2011). Consumer Industry Emerging Trends And Issues Report Of The 2010-2011 Consumer Industry Agenda Council. Geneva, Switzerland. 